\title{
STUDI TENTANG DALALAH MAKNA : Absolutisme dan Relatifisme Ayat-Ayat Hukum dalam Al-Qur'an
}

\author{
Oleh : Saifudin Zuhri
}

Fakultas Ilmu Tarbiyah dan Keguruan Universitas Islam Negeri Walisongo Email : saifudinzubri71@gmail.com

\begin{abstract}
Al-Qur'an is a hammalat li al-wujuh, so that from meaning searching aspect famous with an expression, someone doesn't called mufasir except if he can to give various interpretation toward every verses of al-Qur'an. That is way from the expert of usul and fuqaha inclined give interpret to the alQur'an as Allah's word in meaning lafi $i$ word, because their purpose is for instinbat al abkam. With hammalat li al wujub sure will give the different of law comprehension, even may be happen contradiction in interpretation a verses of ahkam. In term of usul fiqh absolute and relative oftenconnected with their technical term about qat'i and zanni in realize verses of dalalah. Verses that showing absolute is qat'i and which showing relative is zanni. Relativism is concepts which declare that a life value is relative, different according to the conditions development, culture, etc. Conversely absolutism looks at that life a value doesn't change, not relative, but absolute although conditions, culture, and the other experience change. Especially in law side, appear the questions whether law verses in al-Qur'an there has absolute and don't know law development existence causes period development.

It is time for the experts doesn't base on analyses harfiyah-tekstual on law verses which has qat'i. should always understood that abkam verses thinking building fundamental harmony, humanity universals or social justice. Individual interpretation offer towards provision both for qat'i also peace that can to guarantee humanity harmony in the eyes of Islam valid. Approach barer, easy to dialogue and contextual towards verses ahkam with integration in society life make easy to popularizing figh. on the basis of this so law consistence that appointed based on verses ahkam may not quit of mawasid al-hukm li jalbi al-masalih wa dar'i al-mafasid.
\end{abstract}

Key word: al-dalalah; qat'i; ijtihad; al-Qur'an.

\section{Pendahuluan}

Di kalangan ahli usul, istilah qat'i dan zanni masing-masing terdiri dari dua bagian, yaitu menyangkut al-subut (kebenaran sumber) dan al-dalalah (kandungan makna). Dua istilah ini dibagi menjadi dua bagian, ialah qat'iy 
al-subut dan zanny al-subut, serta qatiy ad-dalalah dan zanny ad-dalalah. Apakah ayat-ayat al-Qur'an mengenal zanny al- wurud? Semua ulama sepakat bahwa al-Qur'an tidak mengenal zanny al-wurud. Al-Qur'an jelas qat'iy al-wurud. Artinya dari kebenaran sumber periwayatan al-Qur'an, seluruh redaksi ayat-ayat al-Qur'an yang dihimpun dalam musaf dan dibaca oleh seluruh kaum muslimin di seluruh dunia adalah sama tanpa ada perbedaan sedikitpun dengan yang diterima nabi Muhammd saw. dari Allah melalui malaikat Jibril.

Dari segi ad-dalalah, Quraish-Shihab menyatakan, ulama-ulama tafsir menekankan bahwa al-Qur'an hammalat li al-wujuh sehingga dari segi penggalian makna, terkenal ungkapan, seorang tidak dinamai mufassir kecuali jika ia mampu memberi interpretasi beragam terhadap ayat-ayat alQur'an ${ }^{1}$.Itulah sebabnya para ahli usul dan fuqaha cenderung mengartikan al-Qur'an sebagai kalam Allah dalam arti kalam lafzi, karena tujuan mereka adalah untuk istinbat, menggali dan mengeluarkan hukum dari pada ayatayatnya. Hal ini tidak bisa lain kecuali berkaitan dengan kalam Allah yang bersifat lafzi.

Dari uraian bahwa al-Qur'an itu bammalat li al-wujuh, tentu akan melahirkan pemahaman yang berbeda, bahkan mungkin terjadi kontradiksi pada interpretasi sebuah ayat. Khusus dalam masalah hukum, timbul pertanyaan apakah ayat-ayat hukum dalam al-Qur'an itu ada yang bersifat absolut, mutlak dan tidak mengenal adanya perkembangan hukum lantaran perkembangan zaman?

\section{Pengertian absolut dan relatif}

Secara leksikal absolut berarti mutlak, lengkap, dan tak terbatas. Sedangkan relatif berarti kebalikannya yaitu tidak mutlak, tidak tak terbatas dan tidak lengkap. ${ }^{2}$ Relativisme berarti paham yang menyatakan bahwa nilai-nilai kehidupan itu bersifat relatif, berbeda-beda sesuai dengan perkembangan keadaan, budaya dan sebagainya. Dan sebaliknya adalah absolutisme yang memandang nilai-nilai kehidupan itu tidak berubah, tidak relatif, melainkan mutlak dan tidak berubah sungguhpun keadaan, budaya dan lainnya mengalami perubahan. Dalam term usul fiqh absolut dan relatif sering dikaitkan dengan istilah mereka tentang qat'i dan danni dalam memahami dalalah ayat. Ayat yang menunjukkan absolut disebut qat'i dan ayat yang menunjukan relatif disebut zanni.

Harus ada penyadaran bahwa istilah keqat'iyyan dan kedanniyan nas adalah sebuah ketentuan dari para ahli usul, karena itu ketentuan nas ini qat'i dan nas itu zanni adalah bukan suatu kepastian, karena para ulama usul

\footnotetext{
${ }^{1}$ Quraish-Shihab, Membumikan al-Qur'an, ( Bandung : Mizan, 1992), hlm.137

2 Peter Salim, Kamus Bahasa Indonesia Kontemporer, (Jakarta: Modern Engglish press, 1991)
} 
sendiri ada perbedaan mengenai batasan qat'i dan tidaknya nas. Istilah qat'i dan zanni ini adalah istilah yang berkembang di antara mereka, bukan dari petunjuk langsung dari al-Qur'an bahwa ayat 'a ' adalah absolut dan ayat ' b' adalah relatif, maka jumlah ayat yang danni/relatif jumlahnya bisa berkembang, dan sebaliknya ayat yang qat'i absolut bisa mengalami penyusutan. Di pihak lain, sering juga terjadi perbedaan pendapat, ulama yang satu mengatakan bahwa ayat 'a.' petunjuk maknanya adalah relatif, sementara ulama lain mengatakan ayat 'a' itu maknanya absolut. Jadilah berbeda kesimpulan hukum dan dan berlakunya hukum itu. Pada gilirannya menjadikan masalah fiqih yang sebenarnya bersifat zanni menjadi masalah fiqih yang bersifat qat'i yang tidak boleh berbeda pendapat. Yusuf Qardawi menyatakan, untuk menolak perbedaan pendapat itu biasanya menggunakan pedang Ijma', padahal sesungguhnya belum terjadi Ijma'. Telah dikatakan Imam Ahmad: 'Barang siapa yang mengatakan dalam satu masalah telah terjadi Ijma', sesungguhnya dia berbohong. Sebab bisa saja dia tidak mengetahui bahwa masih banyak orang yang tidak setuju dengan apa yang dikatakan sebagai Ijma' ${ }^{33}$ Misalnya Abu Bakar, Umar dan Usman berpendapat tentang mabjubnya ibu untuk menerima sepertiga harta waris, dia hanya menerima seperenam dari harta waris karena adanya dua saudara laki-laki. Ternyata Ibnu Abbas menyatakan mahjub karena adanya tiga saudara laki-laki mayit. Di dalam al-Qur'an: ${ }^{4}$

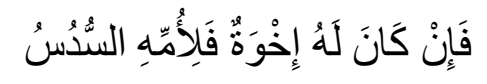

Artinya : "Jika yang meninggal itu mempunyai beberapa saudara, maka ibunya mendapakan seperenam".

Dalam ayat ini dinyatakan beberapa saudara, bukan dua saudara. Bukankah bahasa al-Qur'an ini bahasamu juga? Usman menjawab: "Aku hanya melaksanakan ketetapan yang sudah berlaku sebelum aku". Alasan ini berarti Usman berdasarkan ijma'. Kalau ijma' sebagai hujjah tentunya Ibnu Abbas tidak akan membantah, lagi pula dalam al-Qur'an mempunyai arti yang sangat jelas/qat'i. Dengan demikian alasan Usman yang mendasarkan pada ijma' lebih lemah dibanding makna lahiriyah al-Qur'an yang juga sebagaimana bantahan Ibnu Abbas di atas. Kaitan ini, berarti Ibnu Abbas mendahulukan makna lahiriyah al-Qur'an dari pada ijma' yang disepakati ketiga sahabat tersebut dan orang-orang yang semasa dengan mereka.

Dalam penilaian ayat yang status dalalahnya sama, misalnya ulama yang satu dengan ulama lainnya sama-sama menilai bahwa ayat ' a ' itu menunjukkan makna qat'i ternyata dalam operasional implementasi fiqihnya

\footnotetext{
${ }^{3}$ Isham Talimah, Manhaj Fikih al-Qardhawi, Terj. Samson Rahman, (Jakarta: Pustaka AlKautsar, 2001), hlm.171.

${ }^{4}$ Q.S. An-Nisa , 4:11.
} 
berbeda, bahkan jauh berbeda, misalnya cara membasuh kepala dalam berwudu, cara memotong tangan dalam hukum mencuri dan cara mendera dalam hukum zina dan lain sebagainya.

Di sisi lain, ayat-ayat yang qat'i ada yang meliputi segala keadaan, dan ada juga yang hanya untuk sebagian saja (amm-khas), ada juga yang bersifat mutlak dan ada yang bersifat muqayyad (Mutlak-muqayyad). Dalam hal ini, At-Tufi memerinci sebagai berikut : $:^{5}$ (1) Nas mutawatir dan sarib yang bersifat qat'i dari segi dalalahnya, bila ditinjau dari segi 'amm dan khasnya, dalalahnya bisa mengandung arti yang lain (mukbtamil). Bentuk demikian berada pada nas qat'i tetapi bersifat mutlak; (2) Nas mutawatir dan sarih yang bersifat qat'i dan yang tidak mukbtamil baik dari segi amm-khasnya, maupun segi-segi yang lain, nas tersebut disebut qat'i dari berbagai segi, (3) Nas yang bersifat ahad dan qat'i yang mubtamil, maka tidak disebut qat'i (ada kepastian), dan (4) Nas ahad yang sarib tidak bisa disebut qat'i karena adanya ibtimal dari berbagai segi.

Para sahabat sepakat tentang kebolehan melakukan tayamum karena sakit atau tidak mendapatkan air, berdasarkan ayat al-Qur'an, al-Ma'idah : ${ }^{6}$

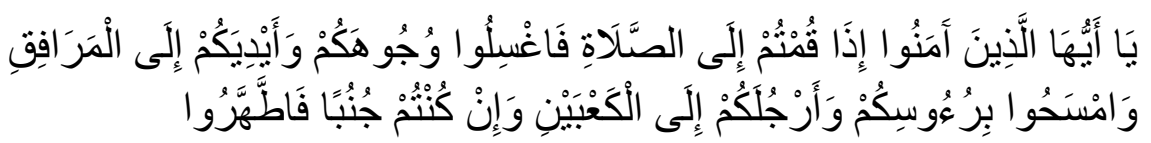

Artinya : "Hai orang-orang yang beriman, apabila kamu hendak mengerjakan shalat, maka basublah mukamu dan tanganmu sampai dengan siku, dan sapulah kepalamu dan (basub) kakimu sampai dengan kedua mata kaki, dan jika kamu junub maka mandilah ..." (QS. Al Maidah: 6)

Ternyata Ibnu Mas'ud tidak sependapat, seraya mangatakan: 'Kalau kita memberikan keringanan untuk itu, dipastikan setiap orang yang merasakan dingin terhadap air, mereka akan melakukan tayamum sekalipun air berada di depan batang hidungnya”. Abu Musa menyanggah pendapat Ibnu Mas'ud seraya mengungkapkan ayat al-Qur'an dan Hadis Ammar,6 tetapi ia tidak mendapatkan tanggapan yang serius dari Ibnu Mas'ud.

\footnotetext{
${ }^{5}$ At-Tufi, Syarah Mukhtas \}ar alRaudah, jilid 3, hlm. 207-208. dan At-Tufi, al-Intisarat, jilid 1 hlm. 1. At-Tufi, al-Bulbul, hlm. 144

${ }^{6}$ Ammar, nama lengkapnya Abu al-Yaqzan Ammar Ibn Basyir, ia termasuk generasi Sahabat yang awal masuk Islam di Makkah kemudian hijrah ke Habsyi dan pada akhirnya hijrah ke Madinah. Nabi menyebutnya orang yang at-Tayyib wa al-Mutayyib. Ia termasuk generasi yang awal hijrah ke Madainah dan banyak terlibat dalam peperangan, ia mati sahid dalam peperangan Badar bersama sahabat lainnya. Ia dibunuh dalam rombongan Ali, ra. Genap berusia 73 tahun. Rasulullah bersabda: Taqtuluka al-fiatu al-Bagiyah. Pada suatu hari ketika diutus Rasulullah untuk suatu kebutuhan, ia mengalami junub, dan tidak mendapatkan air, kemudian ia berguling-guling di tanah (fatamarraga) seperti binatang. Kemudian (setelah pulang) dilaporkan kepada Rasulullah apa yang terjadi pada dirinya.
} 


\section{Ayat-ayat hukum di dalam al-Qur'an}

Hukum (Islam) menurut ahli ushul yaitu, kbitab syari' yang berkaitan dengan perbuatan orang mukalaf (hukum syar'i' amali), yang terdapat dalam al-Qur'an dan al-Sunnah baik secara eksplisit maupun inplisit. Ayat-ayat hukum berarti, ayat-ayat al-Qur'an yang mengatur dan berkaitan dengan tingkah laku dan perbuatan manusia secara lahir. Artinya, tidak termasuk ayat-ayat al-Qur'an yang berkaitan dengan masalah 'aqidat (abkam i'tiqadiyyat) dan masalah moral (abkam khuluqiyyat).

Sebagian ulama menyatakan, ${ }^{7}$ bahwa pada garis besarnya ayat-ayat hukum al-Qur'an terbagi kepada dua bagian, yaitu:

- Pertama, ayat-ayat hukum yang menyangkut masalah ibadah ( احكام العبادات), yang mengatur hubungan manusia secara vertikal dengan Allah SWT, seperti; kewajiban melaksanakan salat, puasa, zakat, haji, dan lainlain.

- Kedua, ayat-ayat hukum yang menyangkut masalah mu'amalah (احكام المعملات), yang mengatur hubungan manusia secara horisontal dengan sesamanya, baik secara individu, masyarakat, maupun antar bangsa. Bila dirinci lebih lanjut, ayat-ayat hukum kelompok kedua ini meliputi tujuh aspek hukum sebagai berikut :

a. Hukum kekeluargaan (احكام الاحوال الثخصية ), yakni hukum yang mengatur hubungan antar anggota keluarga, sejak terbentuknya sampai masa berakhirnya.

b. Hukum perdata ( الاحكام المد نتة ), yakni hukum yang mengatur hubungan antar manusia menyangkut harta dan segala hak-hak mereka, seperti transaksi jual beli, sewa menyewa, gadai, dan lain-lain.

c. Hukum pidana ( الاخكام الجنائية), yakni hukum yang menfatur dan melindungi eksistensi hidup manusia, baik menyangkut nyawa, harta maupun kehormatan mereka.

d. Hukum acara ( احكام المرافعات), yakni hukum yang mengatur tata cara penyelesaian perkara dalam pengadilan, seperti persaksian, sumpah, dan lain-lain.

e. Hukum ketatanegaraan (الاحكام الد ستورية ), yakni hukum yang mengatur hubungan antara penguasa dengan rakyat dalam suatu

(yakni tayamum dengan berguling di tanah). Maka Rasulullah menjawab: Tidak demikan, cukup bagimu mengambil debu dengan tanganmu, kemudian dibasuhkan pada wajah dan kedua tanganmu (muttafaq alaih). Lihat Muhammad ibn Ismail al-Kahalany al-San'ani, Subul as-Salam, syarah Bulugul Maram, jilid 1. (Bandung Dahlan. t.t.), hlm. 95.

7 Lihat: Abdul Wahab Khallaf,Imu Usul al-Fiqh, ( Kairo: Maktabah al-Dakwah alIslamiyah, 1968), hlm. 32-33. 
negara, seperti hak-hak individual dan masyarakat dalam suatu negara, kewajiban penguasa, dan lain-lain.

f. Hukum antarnegara (الاحكام الدولية) , yakni hukum yang mengatur tata hubungan suatu negara dengan negara lainnya, baik antar sesama negara Islam, maupun antar negara Islam dengan negara non Islam, dalam situasi damai ataupun dalam situasi perang.

g. Hukum ekonomi dan keuangan ( الاحكام الا اقتصادية ), yakni hukum yang mengatur tata hubungan dalam bidang ekonomi dan kekayaan, baik milik individu maupun milik negara. Sebagai contoh, kewajiban orang yang tergolong kaya, menyangkut hartanya, terhadap orang miskin, kewajiban penguasa dalam mengelola dan memanfaatkan kekayaan milik mereka untuk kesejahteraan.

Menurut perkiraan para ahli hanya kurang lebih $8 \%$ atau 500 ayat dari seluruh ayat al-Qur'an yang berjumlah 6236 - atau lebih yang berisi ayat-ayat hukum. Rinciannya mengenai ibadah berjumlah 140 ayat; kekeluargaan 70 ayat; perdata 70 ayat; pidana 30 ayat; tata negara 25 ayat; pengadilan 13 ayat;

Hukum ekonomi dan keuangan 10 dan hukum perundang-undangan 10 ayat. $^{8}$ Ditambahkan oleh Ahmad Amin, jumlah ayat mengenai hukum tentang kehidupan kemasyarakatan hanya kira-kira 200 ayat. Selebihnya sebagaimana dikatakan ahli hukum Islam sebagai ayat abkam tidak dapat diterima kecuali dengan cara berlebih-lebihan mengambil kesimpulan. ${ }^{9}$ Tetapi harus diakui bahwa perbedaan penentuan ayat-ayat hukum memang telah terjadi, lantaran adakalanya untuk menentukannya memerlukan upaya istinbat. Ketajaman visi dan pengamatan mereka, latar belakang pendidikan dan kenderungan keahlian yang berbeda ikut menentukan perbedaan itu.

Di sisi lain, tidak setiap ayat hukum dari awal sampai akhir hanya berbicara soal hukum. Ada juga suatu ayat hukum, selain bicara soal hukum juga berbicara soal ajaran lain, seperti dikir dan istigfar. ${ }^{10}$ Karenya Ibnu alArabi dalam surat al-baqarah yang jumlah ayatnya hanya 286 ayat mengandung 1000 perintah, 1000 larangan, seribu hikmah dan 1000 informasi. ${ }^{11}$

Dengan adanya ayat-ayat al-Qur'an tidak banyak membicarakan soal hidup kemasyarakatan umat, ada baiknya. Masyarakkat bersifat dinamis,

\footnotetext{
${ }^{8}$ Harun Nasution, Islam Rasional, (Bandung : Mizan, 1995), hlm. 26- 7 lihat juga Abdul Wahab Khallaf, usul fiqh.

${ }_{9}$ Ahmad Amin , Al-Islam, (Kairo: Al-Maktabah al-Nahdah al-Misriyah, 1966), hlm.228-9

${ }^{10}$ Hasanuddin. AF, Anatomi Perbedaan Qira'at dan pengaubnya terhadap istibat bukum dalam Al-Qur'an, (jakarta: Raja Grafindo Persada, 1995), hlm.200.

${ }_{11}$ Lihat al-Qurtubi, al-Jami' li Abkam al-Qur'an, ( T.tp : Tp,tt,) juz 1, hlm. 132
} 
senantiasa mengalami perubahan dan perkembangan mengikuti peredaran zaman, sementara hukum mempunyai sifat mengikat.

\section{Ragam pendapat tentang penafsiran ayat-ayat qat'i}

Atas dasar al-Qur'an hammalat li al-wujuh, dapat dimaknai bahwa setiap redaksi nas mengandung kemungkinan banyak arti. Bisa saja bagi mutakallim dimaksudkan satu arti, tetapi bagi mustami' mengandung banyak arti. Sebagai analog, sambil pulang dari resepsi perkawinan jam 12.00, malam, karena bersama dengan temannya, ia mengajak untuk silaturahmi (mampir) ke rumahnya: 'Ayo mampir,' begitu katanya. Kata, ayo mampir di atas itu akan berbeda maksudnya kalau orang itu mengajak mampir temannya pada siang hari antara jam 08-10.wib. Bisa jadi, kata ayo mampir pada malam hari itu sekedar basa-basi, sebab kalau sungguh ia mau mampir akan merepotkan, dan kata ayo mampir yang diungkapkan siang hari itu, memang-benar-benar memohon untuk silaturahmi. Itulah sebabnya asy-Syatibi tidak mengakui ada keqat'iyyan pada nas yang berdiri sendiri. Baginya nas qat'i itu tidak berdiri sendiri, melainkan harus ada pendukung nas-nas lain yang bisa menunjukkan bahwa kandungan dalam nas itu bersifat qat'i. ${ }^{12}$ Dalil tentang kepastian wajib salat itu, didukung dengan banyak dalil yang memperkokoh bahwa salat itu wajib, misalnya hadis nabi : Sallu kama raaitumuni usally, ditambah dengan perilaku Rasulullah, Sahabat, Tabi'in dan para ulama yang melakukan salat. Sebab banyak juga bentuk perintah (amar) yang tidak menunjukkan wajib. ${ }^{13}$

Abdullah Ahmed an-Na'im berpendapat bahwa pertimbanganpertimbangan kemaslahatan dapat mengesampingkan suatu aturan yang sebagai kasus terpisah yang bisa diabaikan begitu saja oleh formulasi usul alfiqh. Saya menegaskan bahwa hukum dijabarkan melalui ijtihad, meskipun dengan menolak teks al-Qur'an dan Sunnah yang jelas dan terinci (qati). Menurut saya, berbagai contoh tindakan sahabat Umar itu tidak bisa dianggap menyimpang. Muslimin (baca: para mujtahid) kontemporer memiliki kemampuan untuk melakukan formulasi Usul fiqh dan berhak melakukan ijtihad sekalipun menyangkut masalah yang sudah diatur oleh teks al-Qur'an dan Sunnah secara jelas dan terinci (qat'i), sepanjang hasil ijtihad itu sesuai dengan esensi tujuan risalah Islam. ${ }^{14}$ Munawir Sjadzali dalam gagasannya tentang reaktualisasi ajaran Islam sejak tahun 1985, mulai tahun 90-an mendapatkan sambutan hangat dari berbagai ulama di Indonesia, utamanya reaktualisasi hukum Islam dalam bidang perbankkan

\footnotetext{
12 Asy-Syatibi, al-Muwafaqat, ( Mesir: Dar al-Ma’rifah, tt.), juz 1, hlm 46

13 Asy-Syatibi, al-Muwafaqat, jilid 1, ibid.

14 Abdullah Ahmed an-Ni'am, Dekontruksi Syariab: Wacana Kebebasan sipil, Hak. Asasi Manusia dan Hubungan Internasional dalam Islam, Terj. Ahmad Suaedy dan Amirudin ar-Rani, Cet ke-3, (Yogyakarta: LKIS, 2001), hlm. 57.
} 
dan hukum waris. ${ }^{15}$ Munawir dalam bukunya; Ijtibad Kemanusiaan banyak mengungkapkan ulama-ulama yang menjadi rujukannya di antaranya Abu Yusuf, Izzuddin Ibn Abd as-Salam, Ibn Al-Qayyim, Ibn Taimiyah, Muhammad Abduh, Muhammad Rasid Rida dan Jamaluddin al-Afgani. Dari kalangan Mufassir seperti Tantowi Jauhari, Ahmad Mustafa al-Maragi, dan Sayid Qutub. ${ }^{16}$

Pada akhir kesimpulannya, ia menandaskan kalau kita dengan rasa penuh tanggung jawab kepada Islam-berusaha memahami ajaran Islam yang luhur itu dengan memanfaatkan akal budi, (sekalipun harus menafsirkan ayat qat'i) maka kita bukan yang pertama yang berbuat demikian. Dan hanya dengan meneladani keberanian Umar bin Khatab itu umat Islam tidak akan kedodoran dalam menyongsong abad 21 mendatang dengan perkembangan hidup yang amat pesat nanti. ${ }^{17}$ Dalam kasus pengambilan keputusan hukum, MUI banyak mengeluarkan fatwa yang oleh banyak kalangan dinilai liberal. Fatwa MUI tanggal 1 Juni 1980 tentang seorang wanita Islam tidak diperbolehkan (haram) untuk dinikahkan dengan seorang pria bukan Islam, dan seorang laki-laki muslim tidak di ijinkan menikahi seorang wanita bukan Islam adalah tidak sejalan dengan Al-Qur'an. ${ }^{18}$ Fatwa melarang perkawinan semacam ini karena alasan kerugiannya (mafsadahnya) lebih besar dari pada keuntungannya (kemaslahatannya). Sungguhpun fatwa ini ditunjukkan khusus mengenai kejadian-kejadian di Indonesia, tetapi fatwa ini sungguh radikal, karena bukan saja bertentangan dengan apa yang secara jelas dinyatakan dalam an-nisa: 5, melainkan juga bertentangan dengan teks fiqh klasik yang sepakat memberi ijin kepada seorang laki-laki muslim untuk menikahi seorang perempuan dari abl al-kitab. ${ }^{19}$

Masdar Farid lebih revolosioner mengungkapkan, pada dasarnya tidaklah ada syari'at yang bersifat mutlak, dan secara apriori berlaku untuk segala duruf (waktu, tempat dan keadaan). Sebagai jalan atau cara bagaimana suatu tujuan dicapai, syari'at mestilah bersifat dinamis dan kontekstual. Satu paket syari'at yang cocok untuk mencapai tujuan dalam suatu duruf sosial tertentu dengan serta merta cocok untuk mencapai tujuan yang sama dalam duruf yang berbeda. Ini berlaku bukan saja hanya untuk syari'at yang dirumuskan sendiri oleh manusia, tetapi juga mengena pada syari'at yang ditawarkan oleh Tuhan sebagai ekspresi rahmat-Nya yang berlimpah kepada manusia. Sesungguhnya prinsip relativitas dan kontekstualitas syariat ini

\footnotetext{
${ }^{15}$ Munawir, Reaktualisasi, hlm. 77-78.

${ }^{16}$ Munawir Sjadzali, Ijtibad Kemanusiaan, (Jakarta: Paramadina, 1997), hlm. 45-48.

${ }^{17} \mathrm{Ibid}$, hlm. 76.

18 Q.S. Al-Ma'idah,5:5

${ }_{19}$ Mohammad Atho muhdzhar, Fatwa-Fatwa Majlis Ulama Indonesia : sebuah Studi tentang Pemikiran Hukum Islam Indonesia, 1975-1988, ( Jakarta: INIS, 1993), hlm.100.
} 
sangatlah jelas. Dalam al-Qur'an, prinsip tersebut diakui secara eksplisit dalam ayat yang berbunyi; Li kullin ja'alna min-kum syir'atan wa minhaja. Untuk masing-masing kalian (selaku komunitas yang berbeda), kami canangkan syari'at dan metode yang juga berbeda. ${ }^{20}$ Akan tetapi, lantaran kerangka pemahaman keagamaan yang dogmatis-formalistis seperti diungkapkan di atas, prinsip kontekstualitas yang sejelas itu menjadi kabur dan atau dikaburkan. Akibatnya, apa yang sebenarnya relatif telah dimutlakkan, dan yang sebenarnya dinamis telah distatiskan. Syari'at yang berarti jalan dan cara (wasilah) untuk mencapai tujuan, telah diberi derajat kemutlakan seperti halnya tujuan $(\text { gayah })^{21}$

Karena itu, perlu disadari bahwa untuk mewujudkan suatu lafaz nas itu dalalahnya qat'i harus menafikan arti lain dengan dasar mutawatir, tidak ibtimal dari banyak segi, dan ini adalah sangat sulit. Karenanya peran ijtihad pada nas yang bersifat qat'ipun masih sangat dimungkinkan dalam rangka alIslam Salibun li kulli zamanin wa makanin. Kita akui bahwa nas qat'i itu hanya menyangkut pedoman umumnya bukan dalam arti operasionalnya. Pezina itu dihukum dera seratus kali memang qat'i, Lalu, apakah memang tidak dibenarkan bentuk hukuman lain yang lebih efektif memenjarakan? Kalau hanya cambuk, di samping sangat ringan hukumannya juga mungkin belum bisa menjerakan. Ah, Cuma di cambuk aja, gak sakit! Lebih lanjut, apakah pelaksanaan dera itu dipukul kali seratus, ataukah sekali pukul dengan alat yang diikat yang berjumlah seratus. Dalam hadis: "Pada tiap-tiap 40 ekor kambing zakatnya seekor kambing". Mestinya nas ini bersifat qat'i, tetapi dalam prakteknya Abu Hanifah memalingkan artinya dengan "seharga" seekor kambing dengan argumentasi hakikatnya zakat itu untuk menutup kebutuhan fakir-miskin. Dalam kafarat sumpah, ia membolehkan yang seharusnya diserahkan kepada 10 orang miskin, diserahkan kepada satu orang miskin. Wanita yang sedang haid dilarang melaksanakan tawaf untuk haji, ternyata para ulama dalam pentatbiqiannya melakukan ijtihad. Ada yang memandang tetap tidak boleh sampai ia suci, ulama lain membolehkannya dengan membayar dam seekor unta. Dan sebagian lain membolehkannya tanpa ada dam. Ulama Indonesia menyikapinya dengan membolehkan wanita menggunakan pil penunda haid.

\section{Hermeneutika salah satu metode penafsiran ayat-ayat hukum al- Qur'an.}

Seiring dengan hermeneutika sebagai salah satu metode penafsiran alQur'an, ketika teks al-Qur'an dibaca, dipahami, ditafsīrkan dan ditakwilkan oleh para mufasir dan oleh siapapun juga, maka hermeneutika selalu

\footnotetext{
20 Al-Ma'idah, 6: 48.

21 Masdar Farid Mas'udi, Agama Keadilan : Risalah Zakat(pajak) dalam Islam, (Jakarta: pustaka Firdaus, cet-3, 1993), hal, 126-18.
} 
muncul dan rasanya tidak perlu dihindari. Memang, pada mulanya al-Qur'an adalah kalam Allah yang tanpa suara dan huruf, ${ }^{22}$ namun al-Qur'an yang kita baca sekarang adalah sebuah teks dengan memilih bahasa Arab sebagai sarana komunikasinya. ${ }^{23}$ Pengertian ini yang menjadi pilihan ahli usul. Kita yakini al-Qur'an bersumber dari zat yang metafisis, transendental, pesan dan makna yang dikandungnya tiada lain untuk manusia. Karena itu penggaliannya tidak terlepas dari ra'yu manusia, yang tidak mungkin menggunakan metode khusus sesuai dengan realitas ra'yu ketuhanan. Teks al-Qur'an dikukuhkan dengan ketentuan Tuhan yang absolut-eternal (nas Illahi), namun teks tersebut dihadapkan kepada manusia (teks insani) yang tidak absolut sejak masa awal diturunkannya yang kemudian diikuti pembacaannya oleh Muhammad saw. Pembacaan yang berarti pemahamannya merupakan bentuk paling awal persentuhan teks dengan ra'yu manusia. Di saat sebuah teks telah berhadapan dengan ra'yu manusia, maka sifat sakral dan absolutnya hanya ada pada zat Tuhan, yang pada ra'yu manusia arti teks itu menjadi sesuatu yang bersifat ijtihadi. ${ }^{24}$ Quraish Shihab juga menyatakan bahwa setiap nas al-Qur'an mengandung lebih dari satu dalalah. Bagi pengucapnya, redaksi terebut hanya mengandung satu arti saja, yakni arti yang dimaksudkan olehnya. Inilah yang disebut dalalah haqiqiyyah. Tetapi bagi pendengarnya atau pembacanya, dalalahnya bersifat relatif. Mereka tidak dapat memastikan maksud pembicara. Pemahaman mereka terhadap nas al-Qur'an dipengaruhi oleh banyak hal. Mereka bisa berbeda pendapat. Yang kedua ini dinamakan dalalah nisbiyyab. ${ }^{25}$ Ungkapan ini senafas dengan Syaikh Darrasz, bahwa bukan mustahil jika anda mempersilahkan orang lain memandangnya, makan ia akan melihat lebih banyak dari apa yang anda lihat. ${ }^{26}$

Makna pesan Allah yang terkandung dalam teks al-Qur'an, tidak terlepas dari daya tangkap para mufasirnya tidak sama persis dengan apa yang dikehendaki Allah, karena memang ra'yu manusia tidak akan sampai ke sana. Ra'yu Tuham adalah khalik, sementara ra'yu manusia adalah makhluk. Lebih-lebih bila dikaitkan dengan ruang dan waktu antara keduanya telah

\footnotetext{
22 lihat Harun Nasution, Teologi, hlm 143-144.

${ }^{23}$ Ibnu Hazm berpendapat bahwa al-Qur'an dan Kalam Allah merupakan kata musytarak yang meliputi lima makna: Suara yang dapat didengar dan dieja, makna yang dipahami dari suara itu, suhuf yang suci, al-Mushaf, dan yang ada dalam hafalan. Kalam ini disebut alQur'an dan sekaligus Kalam Allah yang kekal dalam arti yang sesungguhnya. Abu Muhammad Ali ibn Ahmad ibn Sa'id ibn Hazm, Al-Fisal wa al-Milal wa al-abwa' wa al- nibal, jilid 2 (Bairut: Dar al-Kutub, al-Ilmiyah, 1996), hlm. 38-43.

${ }^{24}$ Nasr Hamid Abu Zayd, Naqd al-Kitab al-din, (Kairo: Sina` li al- Nasyr, 1994), cet Ke-2, hlm 126.

${ }^{25}$ Quraish, Membumikan, hlm. 138

26 Ibid.
} 
lama dan jauh berbeda, dan lebih-lebih lagi Allah tidak mempunyai ruang dan waktu. Ketiga unsur, pemberi wahyu (Allah), teks al-Qur'an dan manusia (interpreter), atau istilah lain, tujuan, teks dan tafsīr tidaklah mungkin dipadukan secara hakiki. Karenanya makna teks al-Qur'an berada dalam teks, ra'yu pengarang dan ada pada ra'yu pembacanya. Istilah lain, in the world of the teks, the world of author and the world of reader. Ketiga unsur ini harus benar-benar diperhatikan karena bisa menjadi pembantu dan pada waktu yang sama bisa membelokkan dalam memahami makna suatu teks nas. $^{27}$

Dari segi mantuqnya, redaksinya bersifat tetap (sabit), tetapi dari segi mafhum terhadap redaksionalnya bisa bersifat mutaharrik-mutagayyir. Sifat tetap dan berubahnya suatu nas melekat pada setiap nas sejak pembuatannya sudah dikodifikasikan. Seperti nas al-Qur'an. Sedangkan yang periwayatannya melalui lisan ke lisan, meskipun hanya selang beberapa waktu, seperti hadis Nabi, maka akan menimbulkan multi tafsīr terhadap isi redaksionalnya, dan juga menimbulkan kesamaran dari segi wurudnya. ${ }^{28} \mathrm{Nas-}$ nas semacam ini tetap mengundang perselisihan tentang kejelasan dan kesamaan makna yang dikandungnya. Ditegaskan oleh Abu Zaid, terks itu telah kehilangan sifat permanennya meskipun dalam bentuk redaksionalnya, dan karena itu menjadi garapan ijtihad. ${ }^{29}$ Hukum Waris yang menentukan anak lelaki 2:1 dari pada anak perempuan yang diatur dalam ayat: ${ }^{30}$

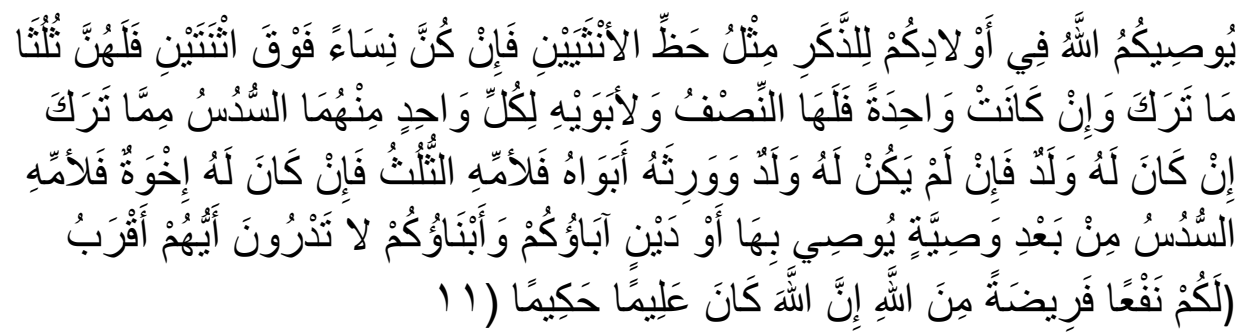

Artinya : Allah mensyari'atkan kepadamu tentang (pembagian warisan untuk) anakanakmu, yaitu bagian seorang anak laki-laki sama dengan bagian dua orang anak perempuan. Dan jika anak itu semuanya perempuan yang jumlabnya lebih dari dua, maka bagian mereka dua pertiga dari harta yang ditinggalkan. Jika anak perempuan itu seorang saja, maka dia memperoleh setengah (harta yang ditinggalkan). Dan untuk. kedua ibubapak, bagian masing-masing seperenam dari harta yang ditinggalkan, jika yang meninggal itu mempunyai anak. Jika orang yang meninggal tidak mempunyai anak dan dia diwarisi

${ }^{27}$ Lihat Ilyas Supena dan M. Fauzi, Dekontruksi dan Rekontruksi Hukum Islam, Yogyakarta: Gama Media kerja sama dengan Program Pascasarjana IAIN Walisongo Semarang, 2002) hlm. 258.

${ }^{28}$ Moh. Thalib, Cara Menyelesaikan Pertentangan Hadis dan Al-Qur'an, (Bandung: Al-Ma'arif, 1979), hlm 20.

${ }^{29}$ Abu Zayd, Naqd al-Kitab, hlm 119

${ }^{30}$ QS. An-Nisa, 4:11 
oleb kedua ibu-bapaknya (saja), maka ibunya mendapat sepertiga. Jika yang meninggal itu mempunyai beberapa saudara, maka ibunya mendapat seperenam. (Pembagian-pembagian tersebut di atas) setelah dipenubi wasiat yang dibuatnya atau (dan) setelab dibayar butangnya. (Tentang) orang tuamu dan anak-anakmu, kamu tidak mengetahui siapa di antara mereka yang lebih banyak manfaatnya bagimu. Ini adalab ketetapan Allah. Sungguh, Allah Maba Mengetahui lagi Mahabijaksana.

Bisa jadi merupakan adaptasi dengan budaya Arab. Dikaitkan dengan unsur historisitas, nas yang bersifat pasti ternyata dipengaruhi oleh sosiokultural masyarakat pra-Islam dan masyarakat Arab sendiri, sehingga kondisi dan unsur budaya melekat menjadi pertimbangan utama. Apa yang ditempuh oleh al-Qur'an merupakan langkah maju yang berisiko tinggi, karena berani sedikit menyimpang dari budaya yang telah mengakar kuat di tengah masyarakatnya. Sebelum Islam hadir di padang pasir Arab, kedudukan wanita tidak lebih tinggi dari pada sekedar barang, sehingga sama sekali tidak ada hak waris. Islam datang untuk mengangkat harkat dan martabat manusia termasuk wanita diangkat dan diakui eksistensinya. Karena dalam teori geneologi Arab menganut patriarchat tribe (kesukuan yang dilacak dari garis laki-laki), maka sangat wajar bila Islam datang masih memberi porsi yang lebih besar kepada lelaki. ${ }^{31}$ Kebanyakan para mufassir memandang bahwa ilmu asbab anl-nuzul inhern tidak bisa dipisahkan ketika seseorang menafsirkan ayat-ayat al-Qur'a, Itulah sebabnya Asy-Syatibi mengemukakan bahwa ketentuan waris 2:1 tersebut termasuk salah satu dari ketentuan pra-Islam yang telah dimodifikasi yang kemudian dilegalisasikan.

Kesadaran adanya pengaruh budaya Arab terhadap ketentuan nas alQur'an bukan dimaksudkan kita berpaling secara mutlak dari ketentuan nas tersebut, melainkan mencari bentuk alternatif ketentuan fiqihnya bagi masyarakat tertentu. Apabila situasi dan kondisi benar-benar berbeda jauh dengan kondisi Arab, tentu alternatif fiqihnya berbeda dengan masyarakat yang kebetulan bercorak sama atau setidaknya mendekati corak masyarakat Arab. Yang terakhir ini, tentu hukum al-Qur'an 2:1 relevan untuk didialogkan atau cukup diimplementasikan saja?. Realitas di masyarakat, banyak juga orang muslim yang mempunyai anak perempuan sebelum mati harta telah dibagi dulu, sehingga setelah meninggal tinggal melaksanakannya. Tiada lain alasanya karena ketakutan terhadap hukum waris, takut anak perempuannya yang menjadi qurrab al-ain tidak mendapatkan warisan yang seimbang.

Hukum potong tangan dalam ayat: ${ }^{32}$

\footnotetext{
${ }^{31}$ Ilyas Supena dan M. Fauzi, Dekontruksi, hlm 265.

${ }^{32}$ QS. Al-Ma’idah, 5:38.
} 


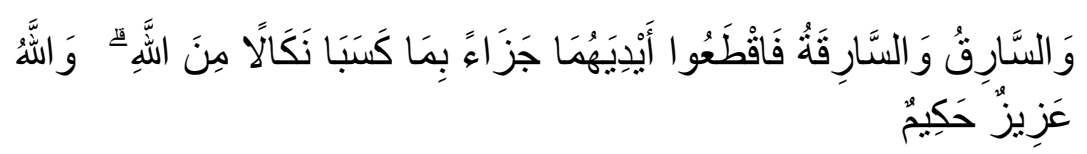

Artinya : Laki-laki yang mencuri dan perempuan yang mencuri, potonglah tangan keduanya (sebagai) pembalasan bagi apa yang mereka kerjakan dan sebagai siksaan dari Allah. Dan Allah Maha Perkasa lagi Maha Bijaksana.

Dipahami secara geografis bahwa jazirah Arab merupakan tanah tandus, tidak subur dan gersang, yang berupa lembah yang dikelilingi gunung, karenanya masyarakat lebih senang melakukan perdagangan sebagai mata pencaharian pokoknya, baik perdagangan lokal maupun internasional. ${ }^{33}$ Karena melimpahnya harta dagangan, timbul adanya pencuri, dan saat itu alat pencurian yang canggih adalah pakai tangan. Maka hukumannya adalah potong tangan. Saat ini, pencuri yang pakai tangan langsung adalah pencuri kelas teri, yang notabene tidak akan mencapai kadar pencurian yang dihukum potong tangan. Lalu, pencuri kelas kakap yang tidak lagi mencuri pakai tangan langsung apa cukup dipotong tangannya? Hemat penulis bisa saja kata 'aidiyadun' ditakwilkan artinya menjadi 'kekuasan', jadi, yang dipotong adalah keuasaannya, atau kemapuannya untuk mencuri sehingga hukumannya adalah potong lehernya. Hukuman bagi pencuri meningkat menjadi hukum mati Dalam hal ini, perlu ada kualifikasi dan klasifikasi tergantung kualitas harta yang dicuri dan kualitas pencurinya. Misalnya ada yang cukup di ta'zir, ada yang cukup di penjara, ada yang cukup dipotong tangan dan ada juga yang sampai harus dihukum mati. Al-hasil hukum potong tangan itu bukan had al- 'a'la (batasan maksimal).

Sisi lain, harta benda yang melimpah dalam bentuk barang dagangan, tentu membangkitkan gairah para pencuri untuk meningkatkan pencuriannya dengan cara menjadi pembegal dan perampok yang menjadi kebanggaan penjahat Arab saat itu. Karena itu ayat sebelumnya: ${ }^{34}$

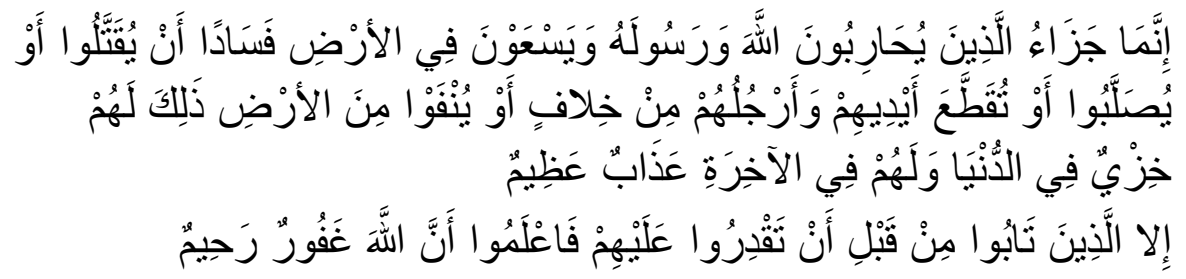

Artinya : Sesunggubnya pembalasan terhadap orang-orang yang memerangi Allab dan Rasul-

Nya dan membuat kerusakan di muka bumi, banyalah mereka dibunuh atau disalib, atau dipotong tangan dan kaki mereka dengan bertimbal balik, atau dibuang dari negeri (tempat kediamannya). Yang demikian itu (sebagai) suatu pengbinaan untuk mereka di

\footnotetext{
33 QS. Ibrahim, 14 : 37 dan AlQuraisy, 106: 1-4.

${ }^{34}$ QS. Al-Ma'idah, 5: 33-34.
} 
dunia, dan di akhirat mereka beroleh siksaan yang besar, kecuali orang-orang yang tobat (di antara mereka) sebelum kamu dapat menguasai (menangkap) mereka; maka ketahuilah bahwasanya Allah Maha Pengampun lagi Maha Penyayang.

Menetapkan hukuman yang sangat berat bagi perusuh dan pengacau keamanan yang kadangkala disertai dengan merampas harta, hukuman yang ditetapkan al-Qur'an pada saat itu memang sangat tepat, karena kejahatan yang merajalela hanya dapat ditanggulangi dengan hukuman yang keras, sehingga orang merasa jera dan takut untuk menerima akibatnya. Robert menuliskan: Rightly or wrongly, the Arabs have long been regarded as a people unequalled in practice of stealing... Robbery and murder were their orinary occupations, for an Arab loked on work or agriculture as beneath his dignity. ${ }^{35}$

Dengan contoh tersebut dapat menjadi bukti bahwa ayat-ayat yang secara redaksional dinilai menunjukkan makna yang jelas, ternyata sangat dipengaruhi situasi, kondisi dan budaya, sehingga masih mungkin untuk mencari bentuk alternatif hukuman yang lain yang intinya tetap terpenuhi aspek zawajirnya. Apalagi kalau kita perhatikan pada al-Ma'idah,5: 33-34 di atas bahwa pelaku perampokan, pembunuhan dan perkosaan yang bertaubat sebelum ditangkap oleh penguasa menjadi gugur hukumannya yang telah ditentukan dalam ayat tersebut. Dalam tindak pidananya yang lebih ringan dari hirabah tentu pengguguran hukuman dengan taubat akan lebih logis lagi.

Ziauddin Sardar menyatakan: The Shariah is like a spriral, confined by ist limits but moving with time, with its norm requiring a fresh effort to understand by Muslims of evey apoch ${ }^{36}$ Ziauddin memberikan contoh hukuman qisas dalam al-Ma'idah, 5 :45 yang membolehkan seseorang untuk menuntut ganti rugi, syari'at menentukan batasan sampai dimana ganti rugi yang boleh dituntut. Karena itu prinsip satu mata untuk satu mata, satu gigi untuk satu gigi dan seterusnya itu mengisyaratkan ganti rugi maksimum yang boleh dituntut seseorang. Batasan itu bukan norma syari'at, melainkan batasan luar yang diperbolehkannya. Norma syari'atnya adalah mengasihi dan memaafkan sebagaimana yang dicontohkan dalam perilaku Nabi. ${ }^{37}$

Syahrur, seorang insinyur dari Syiria memperkenalkan teori budud dalam memahami ayat-ayat al-Qur'an. Melalui 6 macam bentuk hudud. 1). Al-Had al-Al-Adna (batasan minimal, 2). al-Had al-A'la (batasan maksimal), 3). al-Had al-A'la wa had al-Adna ma'an (batasan maksimal dan minimalnya disebut keduanya, 4). al-Had al-a'la wa had al-adna ala nuqtah wahidah (batasan maksimal dan minimalnya bertemu dalam satu titik), 5). Al-had al'a'la bi khat

\footnotetext{
${ }^{35}$ Robert Roberts, The Social Laws of al-Quran, (New Delhi: Kitab Bhavan, t. t.), hlm 90.

36 Ziauddin Sardar, Islamic Futures: The Shape of Ideas to come (Selangor: Pelanduk Publications (M) Sdn. Bhd, 1988), hlm. 119.

${ }^{37} \mathrm{Ibid}$, hlm. 119-120.
} 
muqarib mustaqim (tidak sampai batas maksimal dan juga tidak menyentuh batas minimal), 6). al-had a'la mujib muglaq la ajuz, tajawnquh, wa al-had al-adna salib yajuг, tajawuzah (batas maksimal positif dan batas minimal negatif, serta keduanya bertemu di titik tengah. ${ }^{38}$ Hukuman potong tangan bagi pencuri yang ditegaskan dalam al-Qur'an merupakan al-had al-a'la, karena itu tidak diperbolehkan memberikan hukuman dengan melebihi hukuman potong tangan, tetapi memungkinkan untuk memberikan hukuman yang lebih ringan darinya. Dalam hal ini, mujtahid bebas untuk menentukan bentuk hukuman bagi pencuri sesuai dengan situasi dan kondisi yang dihadapinya. Mana pencurian yang harus dipotong tangan, dan mana yang bukan. Di sini bentuk modus operandi, motivasi pencuri, dan nilai barang yang dicuri, menjadi pertimbangan dalam memberikan hukuman. ${ }^{39}$

Ketentuan bagian warisan 2:1 adalah ketentuan yang menyebutkan batas maksimal sekaligus batas minimal. Ketentuan 2:1 adalah batas maksimal bagi lelaki dan batas minimal bagi perempuan. Ketentuan ini hanya berlaku dalam konteks dimana tanggung jawab perekonomian keluarga sepenuhnya dipikul oleh lelaki, sedangkan perempuan sama sekali tidak ikut menanggungnya. Di sini batas minimal bagian perempuan adalah $33.3 \%$, dan batas maksimal bagian lelaki adalah $66.6 \%$, karena itu apabila lelaki diberi bagian $75 \%$ dan perempuan $25 \%$ tidaklah dapat dibenarkan, karena telah melampaui batas ketentuan hukum Allah. Karena Allah hanya menentukan batas maksimal bagi lelaki, dan batasan minimal bagi perempuan, maka boleh dilakukan ijtihad sesuai dengan konteks ruang, waktu dan personal dengan memperkecil jurang perbedaan bagian keduanya, dan bahkan sampai terjadi persamaan bagian secara sempurna, yaitu 1:1. Pada akhirnya, Sahrur menegaskan bahwa ijtihad itu bersifat dinamis, sehingga fiqh Islam tidak hanya terpaku pada nas yang dibuat ratusan tahun silam secara permanen. Pemaksaan terhadap hal ini justru akan menghilangkan kehanifan sebagai salah satu karakteristik. Islam. Karena itu melarang ijtihad terhadap hukum yang telah ditunjuk nas qat'i ad-dalalah oleh Syahrur dianggap kesalahan besar dalam figh. ${ }^{40}$ Senada dengan Sahrur, bahkan lebih tajam lagi Syaikh Ahmad Zaki Yamani menyatakan bahwa yang membedakan antara illat dan hikmah itu hanyalah bertalian dengan aspek ibadah murni, sedangkan dalam kasus sekuler dan komersial (mu'amalah) illat dan hikmah itu identik. ${ }^{41}$

\footnotetext{
38 Muhammad Syahrur, al-Kitab wa al-Qur'an Qira'ah Mu'asirah, (Damaskus: al-Ahali, 1990), cet ke-2, hlm 453-466.

${ }^{39} \mathrm{Ibid}, \mathrm{hlm}$ 455-456.

${ }^{40} \mathrm{Ibid}, \mathrm{hlm}$. 457-459, 602-603.

41 Amad Zaki Yamani, Syariah yang Abadi Menjawab Tantangan Zaman, terj. Mahyudin Syaf, (Bandung: Al-Ma'arif, 1986), hlm. 41-55.
} 


\section{Memadukan ayat yang absolut dan yang relatif}

Hendaknya selalu dipahami bahwa bangunan pemikiran ayat-ayat ahkam yang fundamental adalah keharmonisan, kemanusian universal atau keadilan sosial. Tawaran ijtihad terhadap nas baik yang qat'i maupun yang zanni yang mampu menjamin keharmonisan kemanusian dalam kacamata Islam adalah sah dan umat Islam terikat untuk merealisasikan. ${ }^{42}$ Karena itu, kata Agiel Sirodj harus ada suatu pembaharuan yang menggunakan pemikiran rasional yang disandarkan pada ketentuan nas. Pemahaman terhadap ketentuan nas itulah yang harus dikembangkan dengan mengoreksi pemahaman lama. ${ }^{43}$ Ketentuan nas dari al-Qur'an yang dipandang qati oleh ulama tertentu bisa jadi hanya zanni oleh ulama lain. Begitu juga nas yang dipandang qat'i pada masa tertentu menjadi zanni pada masa yang lain karena perubahan setting sosial, ilmu pengetahuan dan teknologi, seperti yang pernah dilakukan Umar Ibn Khattab tidak memberikan zakat kepada muallaf karena dinilai sudah tidak ada lagi mu'alaf. Tidak melaksanakan hukum potong tangan bagi pencuri karena masa krisis ekonomi. Lebih dari itu mungkin saja terjadi bahwa suatu nas\} mengandung aspek qat'i dan zanni sekaligus.

Nas-nas yang dalalahnya qat'i ternyata dalam implementasinya (dalam memfiqihkannya) menjadi zanni juga. Ulama usul menyebutnya Qat'iyyun bi'itibarin wa zanniyyun bi'itibarin ukhra. Misalnya tentang membasuh kepala dalam berwudu, apakah dibasuh sebagian kecil, seperempat atau seluruhnya. Berdasarkan ayat al-Qur'an, hukum salat itu wajib, tetapi pelaksanaan salat itu menjadi zanni, maka lahirlah perilaku salat yang berbeda-beda. Distribusi zakat itu qat'i berdasarkan at-taubah:60, tetapi pengertian masing-masing asnaf 8 itu adalah zanni. Bahkan bisa jadi karena dinilai sudah tidak ada lagi salah satu dari asnaf 8 itu, maka asnaf yang tidak ada otomatis gugur. Berkorban dengan menyembelih ternak sebagaimana petunjuk dalam surat al- kausar' wanhar', boleh jadi karena populasi ternak semakin berkurang atau banyak yang mengandung penyakit yang membahayakan manusia diganti berkorban dengan diwujudkan uang seharga ternak. Dalam hukum potong tangan bagi pencuri, timbul pertanyaan, apakah pengertian tangan itu, dari mana kita memotong tangan, apakah semua pencuri dipotong tangannya. Kalau ternyata setelah dipotong tangannya masih mencuri lagi, maka dipotong kaki kirinya. Lalu, kita bisa bertanya, berdasarkan dalil mana ketika pencuri yang kedua dipotong kaki kirinya, sementara ayat al-Qur'an secara pasti hanya ada hukum potong tangan? Dan selanjutnya, bagaimana kalau pencuri itu sudah bertaubat dan sebagainya? Pencuri itu harus

\footnotetext{
${ }^{42}$ Masdar Farid Masudi, dalam Mujamil qomar, NU Leberal dari Tradisionalisme ablissunnah ke Universalisme Islam, (Bandung: Mizan, 2002), hlm. 201.

${ }^{43}$ Ibid.hlm.192.
} 
dihukum, tetapi hukum potong itu bisa jadi merupakan salah satu bentuk hukuman. Pelaku zina itu harus dihukum, tetapi hukum dera itu bisa jadi hanyalah salah satu bentuk hukuman bagi pelaku zina Dan masih banyak contoh-contoh yang lain karena durufnya berbeda, bisa diganti dengan bentuk lain asal tidak terlepas dari ijtihad keqtiyannya ayat itu terletak dimana? Sejalan dengan Li kullin ja'alna min-kum syir'atan wa minhaja. Dari sini, lahirlah ungkapan para ahli usul : qat'iyun fi jami'i al-ahwal au fi ba'di alabwal.

Sebagaimana disinggung di atas, mewujudkan suatu lafaz nas itu qat'i harus menafikan arti lain dengan dasar mutawatir, tidak ibtimal dari banyak segi, dan ini adalah sangat sulit, begitu kata Asy-Syatibi.. Karenanya peran ijtihad pada nas yang bersifat qat'ipun masih sangat dimungkinkan dalam rangka al-Islam Salibun li kulli zamanin wa makanin. Kita akui bahwa nas qat'i itu hanya menyangkut pedoman umumnya bukan dalam arti rincian operasionalnya. Pezina itu dihukum dera seratus kali memang qat'i, tetapi apakah pelaksanaan dera itu dipukul kali seratus, ataukah sekali pukul dengan alat yang diikat yang berjumlah seratus. Atau hukuman itu mutlak harus didera, atau dapat diganti dengan bentuk hukum lain yang justru mereka menjadi jera. Dalam hadis: "Pada tiap-tiap 40 ekor kambing zakatnya seekor kambing". Mestinya nas ini bersifat qat'i karena mutawatir, tetapi dalam prakteknya Abu Hanifah memalingkan artinya dengan "seharga" seekor kambing dengan argumentasi hakikatnya zakat itu untuk menutup kebutuhan fakir-miskin. Dalam kafarat sumpah, ia membolehkan yang seharusnya diserahkan kepada 10 orang miskin, diserahkan kepada satu orang miskin. Wanita yang sedang haid dilarang melaksanakan tawaf untuk haji, ternyata para ulama dalam pentatbiqiannya melakukan ijtihad. Ada yang memandang tetap tidak boleh sampai ia suci, ulama lain membolehkannya dengan membayar dam seekor unta. Dan sebagian lain membolehkannya tanpa ada dam. Ulama Indonesia menyikapinya dengan membolehkan wanita menggunakan pil penunda haid.

Hukum waris itu jelas diatur secara rinci sebagaimana ayat di atas, tetapi rekomendasi MUI tentang jual beli tanah waris yang berukuran kecil, adalah lepas dari nas yang ada, hanya semata-mata bersandarkan maslahah. MUI pada tahun 1984 merekomendasikan bahwa adalah lebih baik jika tanah-tanah warisan yang ukurannya kecil tidak dibagi-bagikan di antara para ahli waris, melainkan dibiarkan utuh sebagai satu kesatuan yang hasilnya dapat dinikmati bersama oleh para ahli waris. Jika hal ini tidak mungkin dilaksanakan, misalnya salah seorang ahli waris sangat memerlukan uang, maka disarankan agar tanah itu dijual kepada ahli waris lainnya. Apabila hal ini masih juga tidak mungkin dijalankan karena tidak ada ahli waris yang mampu membeli tanah warisan tersebut, maka dianjurkan 
supaya tanah itu dijual kepada pemilik tanah di sekitarnya. Kalau tidak bisa dilakukan, maka hendaknya ditawarkan ke umum dari desa yang sama yang beragama Islam.

Melalui contoh-contoh di atas dapat dipahami bahwa ayat-ayat bukum yang qat'i masih mungkin diijtihadi dalam pentatbiqiannya. Tidak cukup satu ayat menunjukan dalalah qat'iyyah. Untuk menentukan makna ayat-ayat yang qat'i tidak semata-mata tergantung pada suatu teks nas saja, melainkan terkait juga pada sejumlah argumentasi yang maknanya disepakati ulama sehingga tidak mungkin lagi dimaknai yang lain, kecuali makna yang disepakati. Dalam hal ini, implementasi ijtihad terhadap ayat-ayat hukum menggunakan analisis bahasa dengan metode bayan, takhsis, taqjid dan tahdid an-nas, dengan berpijak pada realitas kehidupan. Metode ini berarti sama dengan mengimplementasikan ijtihad dengan metode takhsis,baik muttasil maupun munfasil terhadap ayat-ayat hukum yang bersifat qat'i al-dalalah.

Progresifitas dan kreatifitas di dalam pengembangan metodologi hukum Islam ini sebagai bentuk rekontruksi metodologi hukum Islam sebagai upaya isbat al-bukm sejalan dengan perkembangan zaman. Pada gilirannya hukum Islam akan lebih responsif berbicara persoalan keadilan, persoalan pemerataan ekonomi, sosial, politik, budaya, kesehatan, pendidikan, keluarga, ketatanegaraan, keamanan dan lain sebagainya yang benar-benar menyentuh dan membela kepentingan rakyat tertindas, mustad'afin. Pada waktu yang sama implementasi nilai-nilai fiqh ke dalam pembaharuan hukum Islam sejalan dengan proses modernisasi dan perubahan sosial dengan pendekatan yang lebih terbuka, dialogis dan kontekstual, bersifat responsif, integral dalam kehidupan masyarakat, sehingga memudahkan membumikan fiqh. Atas dasar ini, maka ketetapan hukum yang ditatapkannya tidak boleh terlepas dari maqasid al-bukm li jalbi al-masalih wa dar'i al-mafasid.

\section{Kesimpulan}

Untuk mengawal relevansi hukum Islam yang bersifat kemasyarakatan dengan dunia dimana kita hidup ini, sudah waktunya para ulama tidak terpasung oleh analisis harfiyab-tekstual pada ayat-ayat bukum yang bersifat qat'i. Ayat-ayat hukum yang bersifat qat'i yang mengajarkan kebenaran dan tata nilai yang bersifat permanen dan universal, dalam implementasinya perlu jabaran yang lebih rinci yang memungkinkan menampung kebhinekaan dalam berijtihad dan berpikir analisis terhadapnya sehingga memungkinkan kelenturan hukum Islam untuk berkembang sesuai dengan derap peradaban. Hal ini sangat mungkin terjadi apabila para ulama tetap membuka pintu ijtihad secara optimal untuk istinbat al-bukm pada ayat-ayat hukum qat'i. sehingga mampu menjadi prinsip perubahan, elastisitas dan adaptabilitas fiqh. Wallahu a'lam bi as-sawab. 


\section{DAFTAR PUSTAKA}

Abu Zayd, Nasr Hamid, Naqd al-Kitab al-din, Kairo: Sina`li al- Nasyr, 1994. Ahmad Amin, Al-Islam, Kairo: Al-Maktabah al-Nahdah al-Misriyah, 1966.Ali,

Muhammad Kurdi, al-Islam wa al-Hadarat al-Arabiyah, jilid 1, t.t.p: li Janat atTa lif wa an-Nasyr, 1355.H.

Departemen Agama, al-Qur'an dan Tafsirnya

Edwards, Paul (ed), The Encylcopedia of Philosopyy, Vol II, New York: Macmillan, 1972

Hasanuddin. AF, Anatomi Perbedaan Qira'at dan pengarubnya terhadap istibat bukum dalam Al-Qur'an, (jakarta: Raja Grafindo Persada, 1995

Ibn Hazm, Abu Muhammad Ali ibn Ahmad ibn Sa'id, Al-Fisal wa al-Milal wa al-ahwa' wa al- nibal, jilid 2, Bairut: Dar al-Kutub, al-Ilmiyah, 1996

Khallaf, Abdul Wahab, Imu Usul al-Fiqh, Kairo: Maktabah al-Dakwah alIslamiyah, 1968

Kompilasi bukum Islam di Indonesia: Jakarta: Binbaga Islam, Depag, 2000.

Marcea, Eliade (ed) The Encyeclopedie of Religion, Vol VI,New York: Macmillan, 1993

Mas'udi, Masdar Farid Mas'udi, Agama Keadilan : Risalah Zakat(pajak) dalam Islam, Jakarta: pustaka Firdaus, cet-3, 1993.

Muhdzhar, Mohammad Atho, Fatwa-Fatwa Majlis Ulama Indonesia : sebuah Studi tentang Pemikiran Hukum Islam Indonesia, 1975-1988, Jakarta: INIS, 1993.

an-Ni'am, Abdullah Ahmed, Dekontruksi Syariah: Wacana Kebebasan sipil, Hak Asasi Manusia dan Hubungan Internasional dalam Islam, Terj. Ahmad Suaedy dan Amirudin ar-Rani, Cet ke-3, Yogyakarta: LKIS, 2001.

Najar, Abd. Al-Majid, al, Pemahaman Islam: Antara rakyu dan wahyu, terj. Bahruddin Fanani, Bandung: Rusda Karya, 1997.

Nasution, Harun, Islam Rasional, (Bandung : Mizan, 1995

--------, Teologi Islam: Pemikiran dan Gerakan

Qomar, Mujamil, NU Leberal dari Tradisionalisme ahlissunnah ke Universalisme Islam, Bandung: Mizan, 2002

al-Qurtubi, al-Jami' li Ahkam al-Qur'an, T.tp : Tp,tt, juz 1

Roberts, Robert, The Social Laws of al-Quran, New Delhi: Kitab Bhavan, t.t., As-San;ani, Subul as-Salam, syarah Bulugul Maram, jilid 1. Bandung Dahlan. t.t.

Sardar, Ziauddin, Islamic Futures: The Shape of Ideas to come, Selangor: Pelanduk Publications (M) Sdn. Bhd, 1988

Salim, Peter Salim, Kamus Bahasa Indonesia Kontemporer, Jakarta: Modern Engglish press, 1991

al-San'ani, Subul as-Salam, syarab Bulugul Maram, jilid 1. Bandung Dahlan. t.t.

Shihab, Quraish Shihab, Membumikan al-Qur'an, Bandung : Mizan, 1992 
Sjadzali, Munawir Sjadzali, Ijtihad Kemanusiaan, Jakarta: Paramadina, 1997

Supena, Ilyas dan M. Fauzi, Dekontruksi dan Rekontruksi Hukum Islam, Yogyakarta: Gama Media kerja sama dengan Program Pascasarjana IAIN Walisongo Semarang, 2002

Syahrur, Muhammad, al-Kitab wa al-Qur'an Qira'ah Mu'asirah, (Damaskus: alAhali, 1990), cet ke-2.

Asy-Syatibi, al-Muwafaqat, Mesir: Dar al-Ma'rifah, tt.

Thalib, Mohammad., Cara Menyelesaikan Pertentangan Hadis dan Al-Qur'an, Bandung: Al-Ma'arif, 1979

Talimah, Isham, Manhaj Fikih al-Qardhawi, Terj. Samson Rahman, Jakarta: Pustaka Al-Kautsar, 2001

At-Tufi, Najmuddin, Syarah Mukhtasar alRaudah, jilid 3

Tufi, Najmuddin at-, Al-Bulbul fi Usul al-Figh, cet ke-2, Riyad: Maktabah Imam asy-Syafi'i, t.t.

------, Al-Isyarah al-Ilahiyyah ila al-Mababis al-Usuliyah, jilid 1, 2, dan 3 Tahqiq, Abu Asim Hasan ibn Abbas ibn Qutub, Makkah: al-Maktabah alMakiyyah, 2002.

------, At Ta'yin fi Syarkbi al-Arbain An-Nawawi, Tahqiq, Ahmad Haji Muhammad Usman, Makkah: al Maktabah al Makiyah, 1998.

Yamani, Ahmad Zaki, Syari'ah yang Abadi Menjawab Tantangan Zaman, terj. Mahyudin Syaf, Bandung: Al-Ma’arif, 1986. 